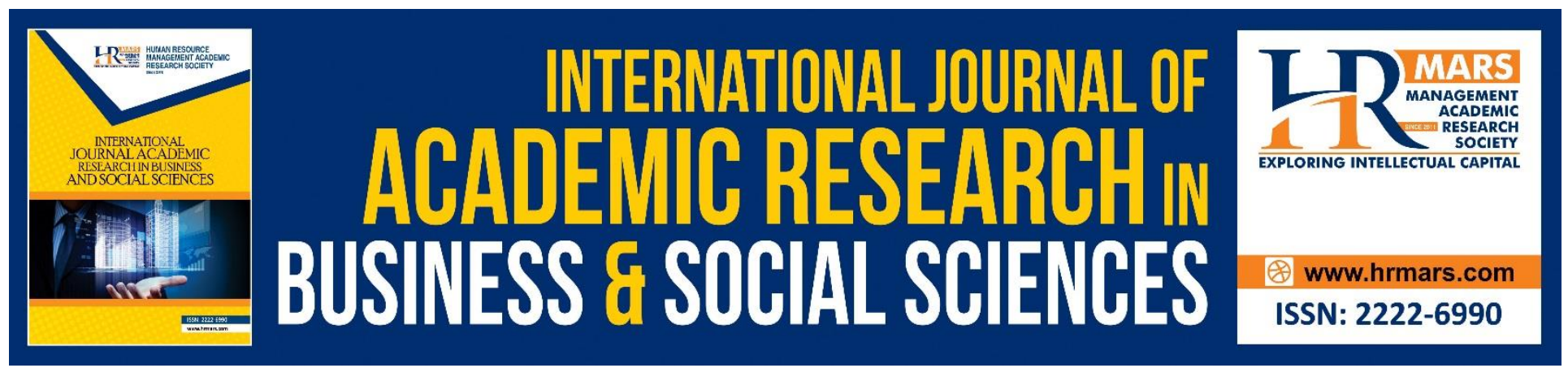

\title{
Can Private Investment Sustain Cocoa Subsector Output in Nigeria? Empirical Evidence using Vector Error Correction Model: $1980-2016$
}

Nwalem, M.P., Asogwa, B.C. and Abu, O.

To Link this Article: http://dx.doi.org/10.6007/IJARBSS/v8-i7/4405

DOI: $\quad 10.6007 /$ IJARBSS/v8-i7/4405

Received: 01 June 2018, Revised: 19 June 2018, Accepted: 29 June 2018

Published Online: 18 July 2018

In-Text Citation: (Nwalem, Asogwa, \& Abu, 2018)

To Cite this Article: Nwalem, M. P., Asogwa, B. C., \& Abu, O. (2018). Can Private Investment Sustain Cocoa Subsector Output in Nigeria? Empirical Evidence using Vector Error Correction Model: 1980-2016. International Journal of Academic Research in Business and Social Sciences, 8(7), 625-635.

Copyright: (C) 2018 The Author(s)

Published by Human Resource Management Academic Research Society (www.hrmars.com)

This article is published under the Creative Commons Attribution (CC BY 4.0) license. Anyone may reproduce, distribute, translate and create derivative works of this article (for both commercial and non-commercial purposes), subject to full attribution to the original publication and authors. The full terms of this license may be seen

at: http://creativecommons.org/licences/by/4.0/legalcode

Vol. 8, No. 7, July 2018, Pg. 625 - 635

http://hrmars.com/index.php/pages/detail/IJARBSS

JOURNAL HOMEPAGE

Full Terms \& Conditions of access and use can be found at http://hrmars.com/index.php/pages/detail/publication-ethics 


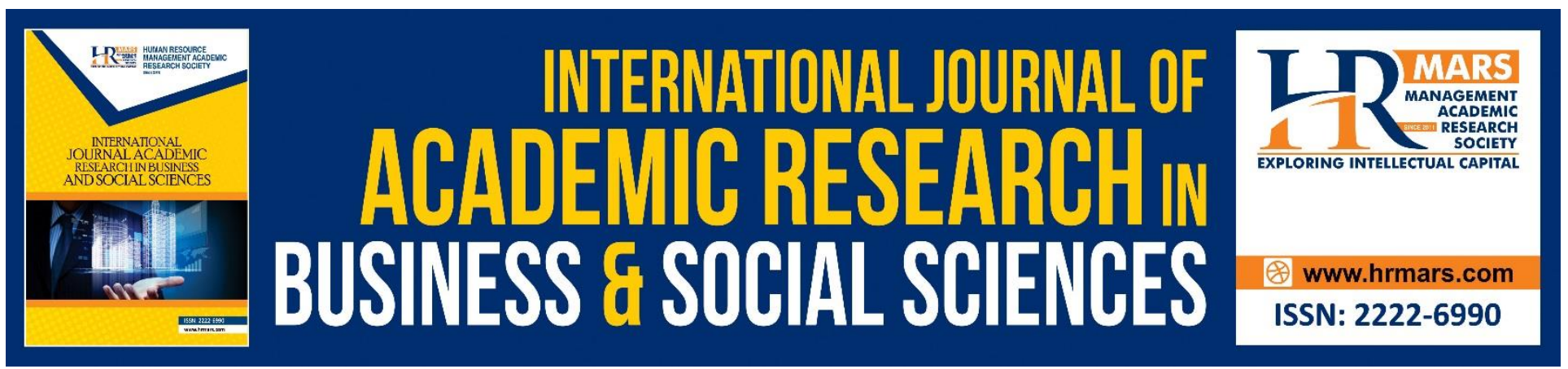

\title{
Can Private Investment Sustain Cocoa Subsector Output in Nigeria? Empirical Evidence using Vector Error Correction Model: 1980-2016
}

\author{
Nwalem, M.P., Asogwa, B.C. and Abu, O. \\ Department of Agricultural Economics, Federal University of Agriculture, Makurdi. P.M.B 2373 \\ Makurdi
}

\section{Abstract}

This study was carried out to analyse effect of private investment on cocoa output in Nigeria using Vector error correction model. Based on the availability of data, secondary data consisting of annual times series covering a period of 37 years (1980-2016) were obtained from World Bank data base, food and agriculture organization and United Nations conference trade and development (UNCTAD). Data were analysed using vector error correction model (VECM) Impulse response and Variance decomposition. Results showed that the direction of cocoa $(-0.001)$ and FDI $(-0.000)$ were negative and significant at $1 \%$ and $5 \%$ level of significance. This implies that the direction of growth of cocoa decelerated over the period under review. In contrast, gross domestic private investment (0.003) was positive and significant at $1 \%$ level of significance. This implies that the direction of GDPI is accelerated over the period under review. Results showed that the coefficient of determination $\left(R^{2}\right)$ was 0.616 indicating that $61.6 \%$ variation in output of cocoa output were explained by cocoa output in the previous year, foreign direct investment in the previous year, gross domestic private investment in the previous year and labour in the previous year. This study showed that a unit increase in labour will decrease cocoa output by $16.65 \%$ and $3.25 \%$ respectively. Furthermore, results showed that cocoa output responded negatively to foreign direct investment and gross domestic private investment in both short and long run. In addition, results also showed that cocoa output responded positively to labour in both short and long run. The result showed that in the short run cocoa output contributed to itself by $82.09 \%$, FDI contributed to cocoa output by $4.23, \mathrm{GDPI}$ contributed to cocoa output by $3.98 \%$ and labour by 9.68 . The result also reviewed that in the long run cocoa output contributed to itself by $80.16 \%$, FDI contributed to cocoa output by $4.91 \%$. GDPI contributed by $4.97 \%$ and labour by $9.93 \%$. In conclusion, cocoa output responded negatively to foreign direct investment and gross domestic private investment in both short and long run. Finally, foreign direct investment contributed mostly to cocoa output in the short run while gross domestic private investment contributed mostly to cocoa output in the long run. It was recommended that 
INTERNATIONAL JOURNAL OF ACADEMIC RESEARCH IN BUSINESS AND SOCIAL SCIENCES

Vol. 8, No. 7, July 2018, E-ISSN: 2222-6990 @ 2018 HRMARS

incentives such as credit facilities, tax reduction and improved seed varieties should be given to domestic and foreign private investors in order to significantly sustain the subsector.

Keywords: Private Investment, Cocoa Output, Error Correction Model

\section{Introduction}

Agriculture has contributed immensely to the growth and development of the Nigerian's economy, with high potentials for employment generation, food security and poverty reduction. Prior to the discovery of oil, Agricultural sector in the early 1960s served as the major source of employment, income and foreign exchange earnings for Nigeria. As at 1961, Nigeria was the leading exporter of groundnut with a world's share of $42 \%$. The country also had $27 \%$ of the world's palm oil export, $18 \%$ of cocoa and $1.4 \%$ of cotton as the major West African cotton exporter. Up to the early 1970 s, agriculture accounted for well over 80 percent of Nigeria's Gross Domestic Product (GDP) and the major value of the country's exports (Oluigbo, 2012). Unfortunately, the future, potentials and prospect of agricultural sector was lost immediately after the discovery of crude oil in the late 1960s and the huge financial gains benefitted from it made the government to shift its priority from agriculture to crude oil and relied on food importation as a means of feeding her citizens (Azih, 2011). Nigerian economy is often described as a mixed economy. A mixed economy connotes a framework in which allocative mechanism in respect of what is to be saved, invested, produced and at what prices, is left to the forces of the market and not to any planning authority or government. The existence of the state is merely to buttress the mechanism and improve its efficiency (Aromoloran, 1998; Udo, 2016). It means that in a mixed economy, private sector should play the leading role while the public sector provides the enabling economic environment. It has been established that private investment is a critical driver of economic growth, indeed Guimaraes and Unteroberdoerster (2006), investigated similar issues with data from Malaysia and found that there is an evidence for a stable long-run relationship between real output growth and investment. Balls (2005) holds similar views that employment possibilities are created through investment and new technologies, thus increasing the revenues, which finally determine economic growth.

In spite of the various agricultural programmes and policies initiated by different administrations for the development of Agriculture in Nigeria, there has not been any phenomenal growth in agricultural output since the 1970s (Akpaeti et al., 2014). Therefore, this study analysed effect of private investment on Cocoa subsector output using vector error correction model.

\section{Methodology}

Study Area: Nigeria derives its name from river Niger, it got her independence in 1960 and it is located at western region of Africa. Nigeria has a land mass area of 923,768.00 sq kilometres and lies between latitude 40 and 140 North of the equator and longitudes 30 and 140 East of the Greenwich meridian. It is bounded on the West by the Republic of Benin on the North by the Republic of Niger and on the East by the Federal Republic of Cameroun. On the North-East border is lake Chad while also extends into the Republic of Niger and Chad and touches the Northernmost part of the Republic of Cameroun. On the South, the Nigerian coast- line is bathed by the Atlantic Ocean. 
INTERNATIONAL JOURNAL OF ACADEMIC RESEARCH IN BUSINESS AND SOCIAL SCIENCES Vol. 8, No. 7, July 2018, E-ISSN: 2222-6990 @ 2018 HRMARS

Method of Data Collection: Based on the availability of data, secondary data consisting of annual times series covering a period of 37 years (1980-2016) were obtained from World Bank data base, food and agriculture organization and United Nations conference trade and development (UNCTAD).

Techniques of Data Analysis: Growth model was used to ascertain direction and growth rates. vector error correction model (VECM) was used to analyse effect of private investment on cocoa output. Impulse response was used to examine response of cocoa output to a unit shock in private investment and Variance decomposition was used to assess contribution of private investment to cocoa output overtime.

\section{Model Specification}

VECM model for the effect of private investment on response of agricultural subsector output In order to estimate the relationship between the variables if cointegration is found, the corresponding vector error correction equation will be estimated as

Where

$$
\ln C_{t-i}=\beta_{0}+\beta_{1} \ln F D I_{t-i}+\beta_{2} \ln D I_{t-i}+\beta_{3} \ln L b_{t-i}+\gamma E C T_{t-i}+\varepsilon_{t}
$$

$C_{t-i}=$ Cocoa subsector output (tons)

$F D I_{t-i}=$ foreign direct investment (Naira)

$D I_{t-i}=$ Domestic Private Investment (Naira)

$L b_{t-i}=$ labour (Mandays)

$E C T_{t-i}=$ Error correction Term

$\varepsilon_{t}=$ error term

\section{Results and Discussion}

TREND OF COCOA OUTPUT

The trend of cocoa is presented in Table 1 and figure 1 . The result showed that cocoa output ranged between 140000 metric tons to 485000 metric ton with the mean of 289097.9 metric tons over the period under review. This implies that between the period of 1980 to 2016, an average of 289097.9 metric tons of cocoa was produced in Nigeria. This could be due to the government policies and programmes on cocoa production in Nigeria. This could also be due to the type of inputs used in cocoa production, availability of labor and capital, the area of land cultivated and environmental factors could also increase or decrease cocoa output. Specifically, the result showed that cocoa output decreases along the following periods as follows: between 1980 to 1983, it decreases from 156000 metric tons to 140000 metric tons; between 1984 to 1987, it decrease from 160800 metric tons to 150000 metric tons; between 1989 to 1990,itdecrease from 256000 metric tons to 244000 metric tons; between 1994 to 1995, it decreased from 306000 metric tons to 203000 metric tons; in 1998 it was 107461 metric tons; and finally, across 2004,2009,and 2015, cocoa outputs were 360570,363510 , and 195000 metric tons respectively. The decrease in cocoa output over these periods could be due to pest and diseases attack, inadequate credit grants to farmers to boost their cocoa farming capacity, limited or fragmented land that discourages mechanization and environmental factors could also reduce the yield of cocoa over the period under review.

The result further showed that the output of cocoa increased over the period under review as follows:1981,1988,1996,1998,2000,2005,2010 and 2016 and their corresponding outputs are 153000 metric tons, 253000 metric tons ,323000 metric tons, 370000 metric tons, 485000 metric tons 
INTERNATIONAL JOURNAL OF ACADEMIC RESEARCH IN BUSINESS AND SOCIAL SCIENCES

Vol. 8, No. 7, July 2018, E-ISSN: 2222-6990 @ 2018 HRMARS

,399200metric tons and 236521 metric tons respectively. This increase in cocoa output could be due to the following reasons; use of improved variety of cocoa with high yielding capacity and pest resistant, cocoa farm mechanization, prosper execution and implementation of cocoa poilicies and programmes, proper handling of cocoa seedlings, inclusion of private and public sector in cocoa production, adequate funding of cocoa project and planting of cocoa seedlings in a conducive and favorable environment could increase its output to a large extent.

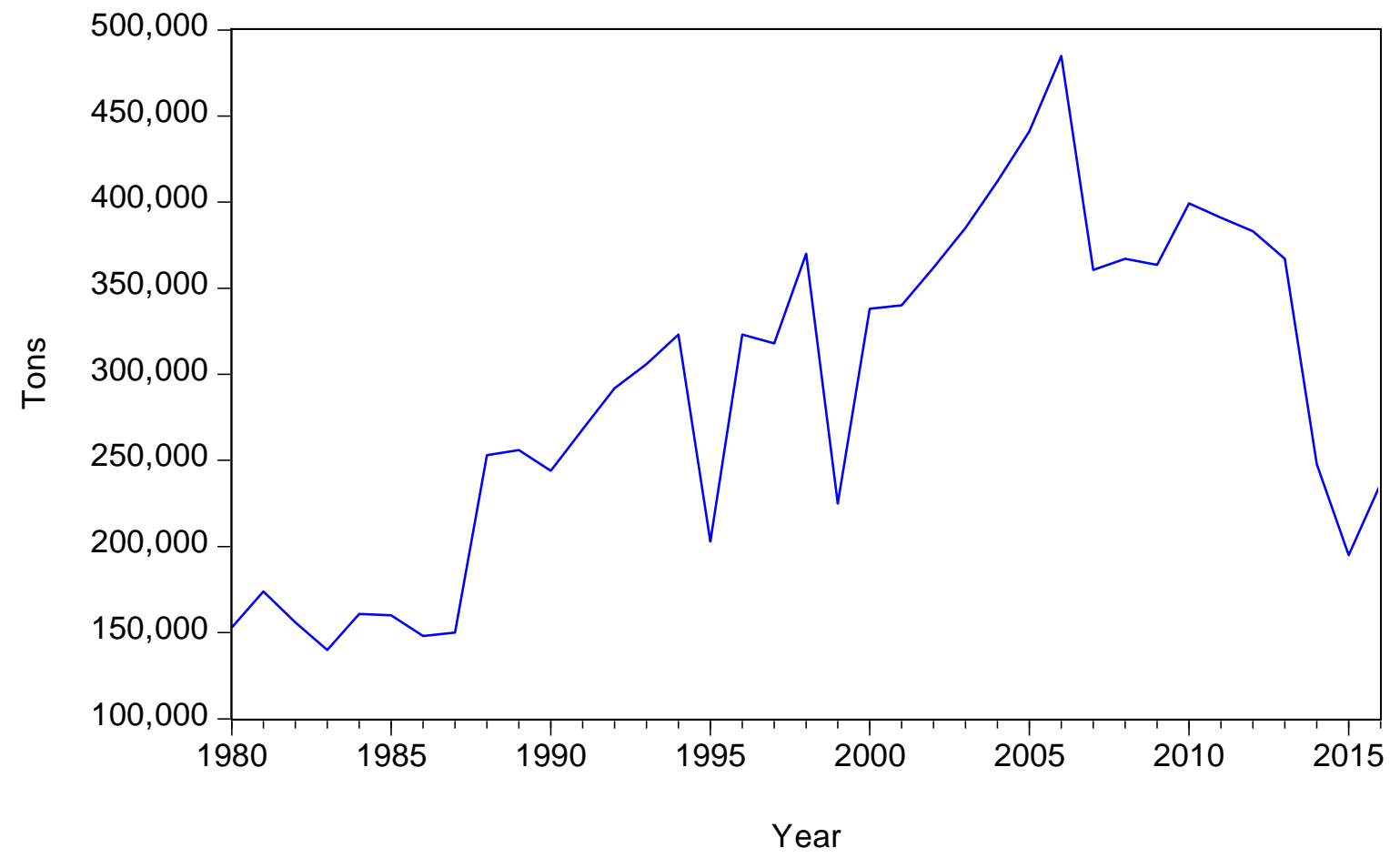

Figure 1: Trend of cocoa output

Table 1: SUMMARY STATISTIC

\begin{tabular}{llll}
\hline Variable & Cocoa & FDI & GDPI \\
\hline Minimum & 140000.0 & $2.46 \mathrm{E}+09$ & $4.18 \mathrm{E}+09$ \\
Maximum & 485000.0 & $1.01 \mathrm{E}+11$ & $2.19 \mathrm{E}+10$ \\
Mean & 289097.9 & $2.96 \mathrm{E}+10$ & $1.02 \mathrm{E}+10$ \\
Observations & 37 & 37 & 37 \\
\hline
\end{tabular}

\section{Direction of Growth}

The result of the direction of growth is presented in Table 2. The result showed that the direction of cocoa $(-0.001)$ and FDI $(-0.000)$ were negative and significant at $1 \%$ and $5 \%$ level of significance. This implies that the direction of growth of ccocoa was decelerated over the period under review. This could be due to inconsistency in government agricultural targeted programmes on cocoa in Nigeria. 
INTERNATIONAL JOURNAL OF ACADEMIC RESEARCH IN BUSINESS AND SOCIAL SCIENCES

Vol. 8, No. 7, July 2018, E-ISSN: 2222-6990 @ 2018 HRMARS

FDI is also decelerated over the period under review and it could be due to the fiscal and monetary policy set up by the Nigeria government. In contrast, the result showed that gross domestic private investment (0.003) was positive and significant at $1 \%$ level of significance. This implies that the direction of GDPI is accelerated over the period under review. The acceleration of GDPI could due flexible macroeconomic that attracts domestic private investors. These policies may be in form of tax reduction, tax holiday, stable exchange rate and interest rate and adequate security that will guarantee the safety of life and properties could accelerate GDPI in Nigeria.

Furthermore, the result of growth rate is presented in Table 3. The result showed the growth rate were positive for cocoa, FDI and their corresponding values are $8.95 \%$ and $12.26 \%$ respectively for instantaneous growth rate and $9.36 \%$ and $13.04 \%$ for compound growth rate. Conversely, the result also showed that the growth rate of GDPI was negative with instantaneous and compound growth rates of -12.01 and -11.31 respectively.

Table 2: Direction of Growth

\begin{tabular}{llll}
\hline & Cocoa & FDI & GDPI \\
\hline Constant & 11.709 & 21.668 & 23.335 \\
@Trend & 0.089 & 0.122 & -0.120 \\
@ Trend & $-0.001 * * *$ & $-0.000 * * *$ & $0.003 * * *$ \\
$\mathrm{t}-$ value & -5.962 & -3.230 & 8.317 \\
$\mathrm{R}^{2}$ & 0.725 & 0.988 & 0.713 \\
F-value & 48.671 & 1515.284 & 45.762 \\
Akaike criterion & -0.389 & -1.348 & 0.457 \\
Durbin-watson stat & 1.249 & 0.376 & 0542 \\
& & & \\
Pro(f-statistic) & $0.000 * * *$ & $0.000 * * *$ & $0.000 * * *$ \\
& & & \\
Decision & Decelerated & Decelerated &
\end{tabular}

$* * *$ indicates stationary at $1 \%$ level of significance

Table 3: Instantaneous and Compound Growth Rate

\begin{tabular}{|l|l|l|}
\hline & Instantaneous \% & Compound Growth \% \\
\hline $\begin{array}{l}\text { Foreign direct investment } \\
\text { (FDI) }\end{array}$ & 12.26 & 13.04 \\
\hline
\end{tabular}


INTERNATIONAL JOURNAL OF ACADEMIC RESEARCH IN BUSINESS AND SOCIAL SCIENCES

Vol. 8, No. 7, July 2018, E-ISSN: 2222-6990 @ 2018 HRMARS

\begin{tabular}{|l|l|l|}
\hline $\begin{array}{l}\text { Gross domestic private } \\
\text { investment (GDPI) }\end{array}$ & -12.01 & -11.31 \\
\hline Cocoa & 8.95 & 9.36 \\
\hline
\end{tabular}

\section{Stationarity Test (Unit Root Test)}

The result of the stationarity test is presented in table 4 . The result showed that all the variables were stationary at first difference.

Table 4: Augmented Dickey-Fuller Unit Root Test Result

\begin{tabular}{llclll}
\hline Variables & \multicolumn{2}{c}{ Level } & \multicolumn{2}{c}{ First difference } & Decision \\
& t-statistic & Probability & t-statistic & Probability & \\
\hline Cocoa & -2.15 & 0.2262 & -7.80 & $0.0000^{* * *}$ & $1(1)$ \\
FDI & -1.25 & 0.6393 & -5.17 & $0.0002 * * *$ & $1(1)$ \\
GDPI & -1.35 & 0.5949 & -5.17 & $0.0010^{* * *}$ & $1(1)$ \\
Labour & -0.00 & 0.9522 & -9.75 & $0.0000 * * *$ & $1(1)$ \\
\hline
\end{tabular}

$* * *$ indicate stationary at $1 \%$ level of significance

**MacKinnon-Haug-Michelis (1999) p-values Source: Eview computation,2018

\section{Cointegation between private investment and cocoa}

The result of cointegration test between private investment and cocoa output is presented in Table

5. The result showed trace statistic ( 67.42) was greater than critical value (63.87) indicating that there is long run relationship between private investment and cocoa output with one cointegration equation

Table 5: unrestricted Cointegration Rank Test Result on Cocoa 


\begin{tabular}{lllll}
\hline \hline $\begin{array}{l}\text { Hypothesized } \\
\text { No. of CE(s) }\end{array}$ & Eigenvalue & $\begin{array}{l}\text { Trace } \\
\text { Statistic }\end{array}$ & $\begin{array}{l}\text { 0.05 } \\
\text { Critical Value }\end{array}$ & Prob.** \\
\hline \hline None ${ }^{*}$ & 0.598861 & 67.42832 & 63.87610 & 0.0244 \\
At most 1 & 0.489660 & 35.45763 & 42.91525 & 0.2267 \\
At most 2 & 0.201296 & 11.91389 & 25.87211 & 0.8179 \\
At most 3 & 0.109197 & 4.047128 & 12.51798 & 0.7353 \\
\hline \hline
\end{tabular}

Trace test indicates 1 cointegrating eqn(s) at the 0.05 level

* denotes rejection of the hypothesis at the 0.05 level

** MacKinnon-Haug-Michelis (1999) p-values

Source: Eview computation,2018

\section{Effect Private Investment on Cocoa Output}

The result of the effects of private investment on cocoa is presented in Table 6 . The result showed one cointegrating equation. The result of the cointegrating equation showed that the coefficient of determination $\left(\mathrm{R}^{2}\right)$ was 0.616 indicating that $61.6 \%$ variation in output of cocoa output were explained by cocoa output in the previous year, foreign direct investment in the previous year, gross domestic private investment in the previous year and labour in the previous year. The result further showed that in the long run labour was the only variable that significantly affected cocoa output. Therefore, the null hypothesis that states that GDPI and FDI have no significant effect on cocoa output is accepted. Specifically, the coefficient of labour (-16.65) was positive and significant at $10 \%$ level. This implies that a unit increase in labour will reduce the output of cocoa by $16.65 \%$. This could be due to marginal product of labour, that is, changes in output that result from employing an additional unit of labour while holding other factors constant. The output will continue to drop until labour becomes negative. It could also be due lack incentives and motivation by the employers of labour which makes the labourers to put less effort in the production process. It could also be due to the drudgery involved in cocoa farming that gets the active and agile youths discouraged in cocoa farming activities. 
INTERNATIONAL JOURNAL OF ACADEMIC RESEARCH IN BUSINESS AND SOCIAL SCIENCES

Vol. 8, No. 7, July 2018, E-ISSN: 2222-6990 (C) 2018 HRMARS

The result further showed that in the short run, labour was the only variable that significantly affected cocoa output. Specifically, the coefficient of labour (-3.25) was negative and significant at $10 \%$ level. This implies that a unit increase in labour would decrease the output by $3.52 \%$. This could be due to rural urban migration by the young active youth in search of white collar jobs thereby leaving cocoa farming to the old men and women in the village. This result disagrees with Audu et al (2017) who found that that labour contributed positively to the output of crop production.

Table 6: Effect of Private Investment on Cocoa Output

\begin{tabular}{|c|c|c|c|c|}
\hline Cointegrating Eq: & \multicolumn{4}{|l|}{ CointEq1 } \\
\hline $\mathrm{D}(\mathrm{LNCOCOA}(-1))$ & \multicolumn{4}{|l|}{1.000000} \\
\hline $\mathrm{D}(\mathrm{LNFDI}(-1))$ & \multicolumn{4}{|l|}{-0.604782} \\
\hline & \multicolumn{4}{|l|}{$[-0.58056]$} \\
\hline D(LNGDPI(-1)) & \multicolumn{4}{|l|}{0.462108} \\
\hline & \multicolumn{4}{|l|}{ [ 1.43312$]$} \\
\hline D(LNLABOUR(-1)) & \multicolumn{4}{|l|}{$-16.65782^{*}$} \\
\hline & \multicolumn{4}{|l|}{$[-7.70152]$} \\
\hline $\mathrm{C}$ & \multicolumn{4}{|l|}{0.488010} \\
\hline & \multicolumn{4}{|c|}{ D(LNCOCOA, D(LNFDI, D(LNGDPI, } \\
\hline Error Correction: & 2) & 2) & 2) & D(LNLABOUR,2) \\
\hline \multirow[t]{2}{*}{ CointEq1 } & -0.23 & 0.000889 & -0.083032 & 0.101338 \\
\hline & {$[-2.82]$} & {$[0.03030]$} & {$[-0.78915]$} & [ 8.17974] \\
\hline \multirow[t]{2}{*}{$\mathrm{D}(\operatorname{LNCOCOA}(-1), 2)$} & -0.388346 & 0.009822 & -0.076906 & -0.121684 \\
\hline & {$[-2.77845]$} & [ 0.20017$]$ & {$[-0.43681]$} & {$[-5.86972]$} \\
\hline \multirow[t]{2}{*}{ D(LNFDI(-1),2) } & -0.697225 & -0.555589 & 0.024835 & -0.030312 \\
\hline & [-1.60594] & {$[-3.64533]$} & [ 0.04541$]$ & {$[-0.47073]$} \\
\hline \multirow[t]{2}{*}{ D(LNGDPI(-1),2) } & -0.005591 & 0.120407 & -0.236947 & -0.040609 \\
\hline & {$[-0.03763]$} & [ 2.30878] & {$[-1.26620]$} & {$[-1.84301]$} \\
\hline \multirow[t]{2}{*}{$\mathrm{D}(\operatorname{LNLABOUR}(-1), 2)$} & $-3.258138 *$ & -0.013513 & -0.582662 & 0.261761 \\
\hline & {$[-3.77470]$} & {$[-0.04459]$} & {$[-0.53590]$} & [ 2.04466] \\
\hline \multirow[t]{2}{*}{$\mathrm{C}$} & 0.001091 & -0.003116 & 0.007307 & -0.001270 \\
\hline & [ 0.02697] & {$[-0.21942]$} & {$[0.14340]$} & {$[-0.21162]$} \\
\hline R-squared & 0.616274 & 0.379460 & 0.125515 & 0.857143 \\
\hline Adj. R-squared & 0.547752 & 0.268650 & -0.030643 & 0.831632 \\
\hline Sum sq. resids & 1.550978 & 0.191139 & 2.460947 & 0.034119 \\
\hline S.E. equation & 0.235355 & 0.082622 & 0.296464 & 0.034908 \\
\hline F-statistic & 8.993751 & 3.424405 & 0.803767 & 33.59995 \\
\hline Log likelihood & 4.243162 & 39.83508 & -3.605064 & 69.12830 \\
\hline
\end{tabular}


INTERNATIONAL JOURNAL OF ACADEMIC RESEARCH IN BUSINESS AND SOCIAL SCIENCES

Vol. 8, No. 7, July 2018, E-ISSN: 2222-6990 @ 2018 HRMARS

\begin{tabular}{lrrrr} 
Akaike AIC & 0.103343 & -1.990299 & 0.565004 & -3.713430 \\
Schwarz SC & 0.372701 & -1.720941 & 0.834362 & -3.444072 \\
Mean dependent & 0.008889 & -0.000528 & 0.008059 & 0.000183 \\
S.D. dependent & 0.349974 & 0.096612 & 0.292024 & 0.085073 \\
\hline
\end{tabular}

Determinant resid covariance (dof adj.)

$3.38 \mathrm{E}-08$

Determinant resid covariance

$1.55 \mathrm{E}-08$

Log likelihood

112.6734

Akaike information criterion

$-4.980790$

Schwarz criterion

$-3.723787$

*indicate stationary at $10 \%$ level of significance respectively

\section{Impulse Response on the Effect of Private Investment on cocoa Output}

The result of the unit shock of private investment on cocoa output overtime is presented in Figure 2. The graph showed that cocoa output responded positively to itself in both short (5yrs) and long run (10yrs). The graph also showed that cocoa output responded negatively to foreign direct investment and gross domestic private investment in both short and long run. The result further showed that cocoa output responded positively to labour in both short and long run

Response to Cholesky One S.D. Innovations
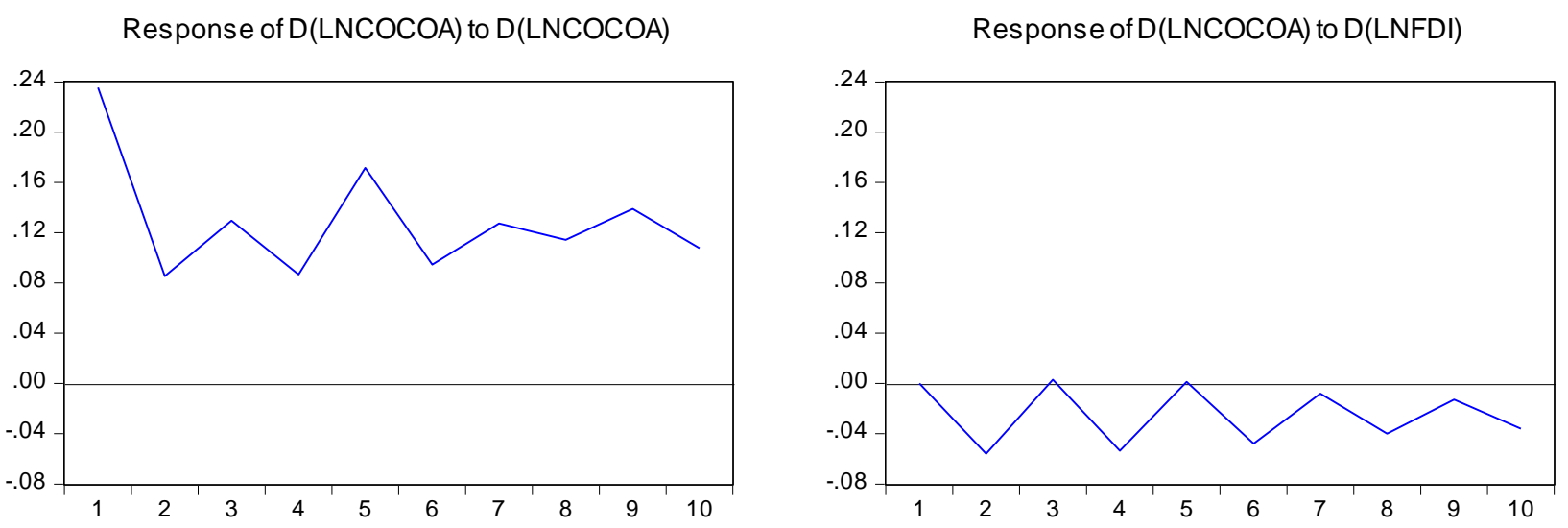

Response of $\mathrm{D}(\mathrm{LNCOCOA})$ to $\mathrm{D}(\mathrm{LNGDPI})$

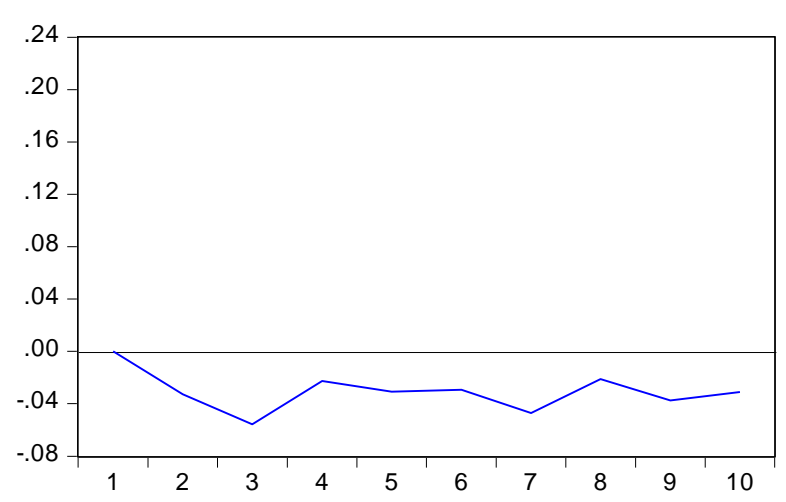

Response of $\mathrm{D}(\mathrm{LNCOCOA})$ to $\mathrm{D}(\mathrm{LNLABOUR})$

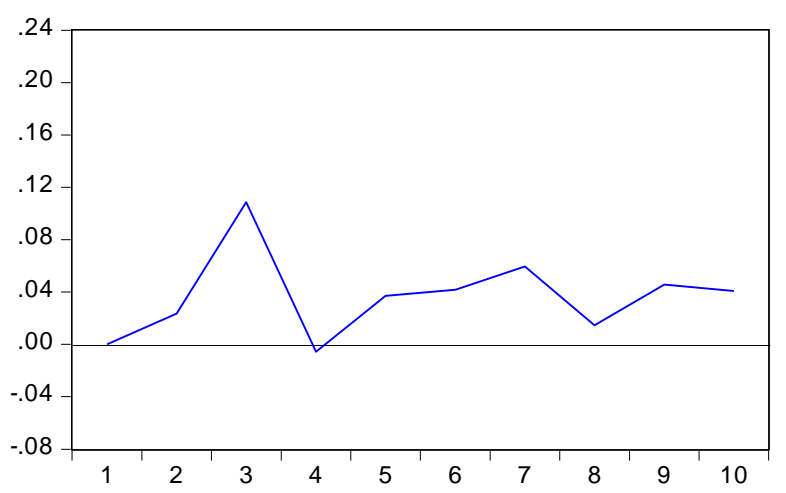

Figure 2. 
INTERNATIONAL JOURNAL OF ACADEMIC RESEARCH IN BUSINESS AND SOCIAL SCIENCES

Vol. 8, No. 7, July 2018, E-ISSN: 2222-6990 (C) 2018 HRMARS

\section{Variance Decomposition on Effects private Investment on Cocoa}

the result of the contribution of private investment to cassava output over time is is presented in Table 7. The result showed that in the short run cocoa output contributed to itself by $82.09 \%$, FDI contributed to cocoa output by 4.23, GDPI contributed to cocoa output by $3.98 \%$ and labour by 9.68 . The result further showed that in the long run cocoa output contributed to itself by $80.16 \%$, FDI contributed to cocoa output by $4.91 \%$. GDPI contributed by $4.97 \%$ and labour by $9.93 \%$.

Table 7: Variance Decomposition for Cocoa Output

\begin{tabular}{llllll}
\hline Period & S.E. & D(LNCOCOA) & D (LNFDI) & D(LNGDPI) & D(LNLABOUR) \\
\hline \hline 1 & 0.235355 & 100.0000 & 0.000000 & 0.000000 & 0.000000 \\
2 & 0.259659 & 92.97704 & 4.625397 & 1.583351 & 0.814209 \\
3 & 0.314838 & 80.18819 & 3.154971 & 4.219721 & 12.43712 \\
4 & 0.331728 & 79.04828 & 5.449481 & 4.270190 & 11.23205 \\
5 & 0.376512 & 82.09686 & 4.231592 & 3.983974 & 9.687572 \\
6 & 0.394430 & 80.55877 & 5.320131 & 4.177955 & 9.943140 \\
7 & 0.421436 & 79.68917 & 4.696862 & 4.905754 & 10.70821 \\
8 & 0.439213 & 80.13468 & 5.144929 & 4.749896 & 9.970497 \\
9 & 0.464610 & 80.56139 & 4.673213 & 4.890107 & 9.875291 \\
10 & 0.480992 & 80.16523 & 4.918636 & 4.979754 & 9.936383 \\
\hline
\end{tabular}

\section{CONCLUSION AND RECOMMENDATIONS}

This study was carried out to analyse effect of private investment on Cocoa subsector output using vector error correction model. The result found that trend of cocoa output undulated and decelerated, foreign direct investment also decelerated while gross domestic private investment accelerated during the period of study. Also, results show that both foreign direct investment and gross domestic private investment have no significant effect on Cocoa output during the period under review. Furthermore, that cocoa output responded negatively to foreign direct investment and gross domestic private investment in both short and long run. Finally, foreign direct investment contributed mostly to cocoa output in the short run while gross domestic private investment contributed mostly to cocoa output in the long run.

It was therefore recommended that:

i) Given that private investment does not significantly affect cocoa output, incentives such as credit facilitiest, tax reduction and improve seed varieties should be given to domestic and foreign private investors through in order to significantly sustain the subsector.

ii) Targeted programmes such as youth empowerment scheme aimed at reducing rural and urban migration should be set up, given that labour negatively affect cocoa output in both long and short run. 
INTERNATIONAL JOURNAL OF ACADEMIC RESEARCH IN BUSINESS AND SOCIAL SCIENCES

Vol. 8, No. 7, July 2018, E-ISSN: 2222-6990 @ 2018 HRMARS

\section{References}

Akpaeti, A. J. , Bassey, N. E., Okoro, U. S., Nkeme, K.K.(2014). trends and drivers of agricultural investments and growth in nigeria: the pre and financial sector reforms experience.

Asian Journal of Economic Modelling. 2(3): 115-127

Aromolaran, A. B. (1998). Public Enterprise Investment, Industrial Development and Privatization in Nigeria: A. Conceptual Framework. In: Ben A. Aigbokhan, ed: Rekindling Investment for Economic Development in Nigeria. The Nigerian Economic Society, Ibadan, pp 103-120.

Azih, I. (2011). A background analysis of the Nigerian agricultural sector (1998 to 2007) available at http:www.manufacturingnigeria.com/index.php/analysis Federal Government of Nigeria (FGN), (2008). National Food Security Program. Federal Ministry of Agriculture and Water Resources, Abuja, Nigeria. Federal Ministry of Agriculture and Rural Development (FMARD), (2011). Agricultural transformation agenda: we will grow Nigeria's agricultural sector. Draft for Discussion. Fertilizer Suppliers Association of Nigeria (FESPAN), (nd) Newsletter Volume 2 No 5

Balls, A. (2005). How Government Spending Slows Growth. Retrieved 2014, from www.nber.org: www.nber.org/digest/jan00/w7207.html.

Guimaraes, R. and Unteroberdoerste, O. (2006). What's Driving Private Investment in Malaysia Aggregate Trends and Firm-Level Evidence. International Monetary Fund (IMF) working paper. WP/06/190

Udo N. E. (2016). Determinants of Private Investment in Nigeria: An Empirical Exploration. Journal of Economics and Sustainable Development,7(11): 2222-285

Oluigbo, C. (2012), "Achieving food self sufficiency in Nigeria”. Business day Newspaper, 29th Feb The Extension Transformation Group (TETG), (2011), "Final report of the agricultural extension transformation component of the Agricultural Transformation Agenda of the Federal Ministry of Agriculture and Rural Development.", Vol. 1: Main Report. 